čím vo svojom diele sprístupňuje fenomén náboženstva širokej verejnosti ovel'a účinnejšie.

Kniha Šamani, mesiáši, proroci a reformátori je vel'mi pekným príkladom modernej religionistickej literatúry a odporúčame ju do pozornosti nielen vedeckých pracovníkov, ale aj študentov a laickej verejnosti.

Juraj Skačan

\author{
Mgr. Juraj Skačan, PhD. \\ Univerzita Konštantína Filozofa v Nitre \\ Filozofická fakulta \\ Katedra filozofie \\ Hodžova 1 \\ 94974 Nitra \\ Slovenská republika \\ jskacan@ukf.sk
}

\title{
Vladimír Manda - Richard St'ahel - Tomáš Pružinec: Človek, sloboda a vlastníctvo vo filozofii raného novoveku.
}

Bratislava, IRIS 2015, $186 \mathrm{~s}$.

Triáda človek - sloboda - vlastníctvo predstavuje trojicu nití, ktoré sa vinú dejinami filozofického myslenia a môžu nás priviest’ až k jeho koreňom. Autori knihy, ktorá nesie túto triádu pojmov vo svojom názve, pochopili neoddelitel'nost' jej jednotlivých súčastí: vymedzenie otázok týkajúcich sa človeka, slobody a vlastníctva nie je možné skúmat’ jednotlivo, ale len vo vzájomnej nadväznosti.

Trojica myslitel’ov, ktorých si autori „adoptovali“ pre účely rekonštrukcie ideových diskusií raného novoveku, reprezentuje tri míl'niky artikulujúce problematiku filozofickej antropológie, podôb slobody a vlastníctva odlišnými spôsobmi. Ani jeden z nich nebol súčasníkom toho druhého. Kým Étienne de La Boétie zastupuje dynamickú realitu humanizmu a renesancie, ktorý bol antitézou dogmatického a skostnateného sveta stredovekého scholasticizmu, John Locke je figúrou éry vrcholného zápasu empirizmu a racionalizmu. Preromantický JeanJacques Rousseau, neoblomný kritik spoločenských pomerov v predvečer Vel'kej francúzskej revolúcie, symbolizuje predzvest' vít'azstva novej éry spontánnosti, intuície a sentimentalizmu, pohŕdajúcej empíriou aj vypätým racionalizmom.

Prvý z trojice autorov, Tomáš Pružinec, predstavuje francúzskeho právnika, filozofa a spisovatel'a Étienna de la Boétieho a jeho dielo Rozprava o dobrovolnom 
otroctve. Kým generačne blízky Niccolo Machiavelli je notoricky známy, La Boétie ako dlho zabudnutý autor trpí na syndróm zabudnutia vel'akrát aj v súčasnosti. Preto treba ocenit' úsilie autora prvej kapitoly priblížit' v jej úvode život, publikačnú tvorbu a dobový kontext Étienna de La Boétieho. Renesančný myslitel' je vykreslený ako „verný dedič“ humanizmu, ktorý oslavuje slobodu ako prirodzenú podstatu človeka. Kategorický výber medzi ontologicky radikálnou slobodou, alebo neslobodou predstavuje napätie medzi vznešeným ciel'om človeka napíňat' prirodzenú túžbu po slobode a dobrovol'nom pritakávaní životu v otroctve. La Boétie má pritom na mysli neslobodu nie ako systémovú charakteristiku, ale uvažuje o nej v sociopsychologických medziach - jej príčina neprichádza zvonku, ale spočíva v samotnom subjekte, v l'ud'och. Prejavuje sa ako fiktívna sloboda: nesloboda, ktorá nebolí; zabudnutie na slobodu a pasívne uspokojenie sa so status quo. Pružinec interpretuje La Boétieho koncipovanie neslobody ako falzifikované sebauspokojenie, v ktorom sa l'ud klamlivo veselí a hoduje, pretože si na neslobodu navykol tak, že sa mu prestala javit' ako neprijatel'ná a už sa mu viac necnie za slobodou.

Na tyranii sa l'ud priživuje a profituje z nej: hoci človeku v tyranii nepatrí ani vlastná osoba, kvôli získaniu majetku je schopný slúžit' systému neslobody, pričom ide o začarovaný kruh obohacovania a zdierania. V Rozprave t’ažko nájst' rozvinuté reflexie o vlastníctve, tak aj o človeku. Neponúka odpovede na otázku, kto je človek, ale koncentruje sa na jeho slobodu a priestor, v ktorom sa pohybuje. La Boétiho človek je sám sebou, slobodný, no priatel'ský, so sociálnymi väzbami a putom vzájomnosti s druhými (solidaritou).

Tomáš Pružinec tlmočí odkaz Étienna de La Boétiho. Dobrovol'ná nesloboda a zotročenie prebieha v súčasnosti na základe súhlasu človeka, ked' sa podvol'uje systému masmédií, náboženstva, konzumného spôsobu života s vidinou pohodlnejšieho života. Zrejme prekvapuje viac nás, než renesančného filozofa, že v našich demokraciách sa „l'udia zaoberajú viac svojou slobodou a svojimi právami, než svojou neslobodou" (s. 44). La Boétie zostáva postavou, ktorá ešte dnes oslovuje libertariánov i anarchistické hnutia. Jeho myšlienky sa vracajú ako morský príboj: v siločiarach ich rozvíjali priekopníci ako Herbert Marcuse, Michel Foucualt, Noam Chomsky a d'alší.

Anglického myslitel'a Johna Locka bližšie predstavovat' netreba. Rozpojenie človeka a osoby, odlíšenie identity človeka od identity osoby $v$ jeho koncepcii človeka, pripomínajúce, že výraz osoba je právnický výraz pre človeka, ktorý sa vzt’ahuje na jeho skutky, má u Locka podstatne hlbšie dôsledky. Tie Vladimír Manda detailne analyzuje. Poukazuje na paradoxy, do ktorých vedie Locke svoju analýzu človeka. Jeho nesubstančný model osoby sa neopiera o také veci ako duša, dátum a miesto narodenia človeka, jeho jedinečné telesné vlastnosti vrátane odtlačkov prstov, ale o vedomie. Preto, ako keby to, na čo si osoba nespomína, ani nebolo jej súčast'ou. Na otázku, prečo potom trestat' opitého človeka za niečo, čo spáchal, ak 
si na to nepamätá, Locke dáva odpoved', že v týchto prípadoch nemožno s určitost'ou rozoznat', čo je skutočné a čo je predstierané, preto sa opitost' neberie ako dostatočné ospravedlnenie. Trest možno uložit’ z nemožnosti dokázat' neprítomnost' vedomia.

V prirodzenom stave u Locka sa vlastníctvom človeka stáva čokol'vek, čo vyberie zo stavu, v akom to príroda poskytla a zmieša to so svojou prácou. Človek si ale nemôže prisvojit' akúkol'vek vel'kú pôdu, pretože jeho sily aj potreby sú obmedzené. Každý si môže privlastnit' len tol'ko, aby sa získané vlastníctvo v jeho držbe nepokazilo (plody, mäso a pod.). Prekročenie hraníc spravodlivého vlastníctva nespočíva v jeho vel'kosti, nadbytok sa definuje prostredníctvom „zákazu plytvania“. Produkty, ktoré sa nemôžu pokazit', sa nemôžu stat' nadbytočnými alebo presahujúcimi potreby. Výmena statkov krátkodobej spotreby za statky trvanlivé je preto legitímna, vrátane akumulácie zlata a striebra, teda peňazí. Tu Manda poukazuje na d'alší paradox. U Locka môže vlastník rozdávat' nadbytok alebo obchodovat' s ním, hoci mu podl'a prirodzeného zákona nepatrí; totiž s netrvanlivou nadbytočnou čast'ou svojho vlastníctva sa podl'a prirodzeného zákona z jednotlivca stáva akoby zlodej a s tým, čo mu nepatrí, nemôže zaobchádzat' ako so svojím vlastníctvom. Významnou skutočnost'ou je aj to, že v politickej spoločnosti, kde už niet vol'nej alebo spoločnej pôdy, prestáva byt' práca zdrojom vlastníctva pôdy. Nadobúda čoraz viac podobu námezdnej formy.

Vladimír Manda identifikuje v Lockovom myslení dve podoby slobody; jedna má všeobecno-abstraktný a metafyzický charakter, druhá je orientovaná do konkrétnych spoločensko-historických proporcií. Dôležitou pripomienkou je Lockova inklinácia k pozíciám racionalizmu, hoci je často považovaný za predstavitel'a empirizmu. Na mnohých miestach zdôrazňuje dôležitost' primeraného používania rozumu. Pri morálnom zdôvodňovaní vol'by večnej blaženosti kladie dôraz na l'udský rozum. Svedčí o tom tiež jeho názor, že čisto na základe racionálnej úvahy možno dospiet' k tomu, že je lepšie konat' tak, akoby posmrtný život jestvoval.

John Locke si uvedomoval prítomnost' priepastných majetkových a sociálnych rozdielov ako dôsledok ekonomickej nerovnosti. Na druhej strane ekonomickú nerovnost' považoval za prirodzený atribút l'udskej spoločnosti. Jej legitimitu odvodzoval z „tichého súhlasu“, ktorým l’udia prikývli vzniku peňazí. Bol presvedčený o tom, že človek má mat’ určité politické slobody, no rovnakú mieru politickej slobody nemusia mat' nevyhnutne všetci občania. Manda správne poznamenáva, že Locke nebol apologétom demokracie ani rozšírenia všeobecného volebného práva. Na druhej strane Lockova argumentácia nezadáva ani žiadnu bázu pre obmedzovanie volebného práva.

Ak v rámci tejto kapitoly bolo $\mathrm{v}$ poznámke pod čiarou podotknuté, že čítanie Locka má svoju evolúciu, a že kým bol v 19. storočí vnímaný ako otec anglického socializmu a jeho liberálne čítanie začína od roku 1930, tak treba povedat', že napreduje ešte v jednej veci, ktorú autor v súvislosti s Lockovou netematizáciou de- 
mokracie opomína. Americký politológ Ian Shapiro odhal'uje, že v Druhom pojednaní je úplne explicitne základom politickej legitimity majoritárna logika, súhlas väčšiny a l'udové poverenie. Aj ked' Locke nerozvíja otázky zastupitel'ských inštitúcií alebo participácie, t’ažko mu upriet', že v tomto zmysle je Locke teoretik demokratickej legitimity a jeho poňatie vlády väčšiny je pre súčasné fungovanie demokratickej politiky hlboko reálpolitické.

Z pohl'adu súčasnosti je najväčším prínosom Johna Locka v oblasti náboženskej slobody jeho oddelenie duchovnej sféry a sféry civilného života. Dnes sa tomu v Európe hovorí „sekularizmus“ alebo „laïcité“. Náboženstvo sa stáva čisto súkromnou záležitost'ou človeka: aby mohol vzniknút’ štát, rozdielne náboženské predstavy museli byt' odsunuté nabok a žiadny jednotlivec nemôže viac posudzovat' a trestat' druhého podl'a svojej viery.

Autor tretej kapitoly zachováva pri analýze diela Rousseaua podobnú postupnost'. Na jej mnohých miestach zdôrazňuje nadčasovost' myšlienok Jeana-Jacquesa Rousseaua. Ako tvrdenie proti nadhistorickému vnímaniu mnohých fenoménov súčasnosti možno považovat' jeho myšlienku, že väčšina rozdielov typických pre l'udí sa považuje za prirodzenost', hoci sú dielom tradície a životných štýlov osvojených spoločnost'ou. „To, čo deformuje l'udskú prirodzenost', je teda spôsob socializácie, ktorý je taký účinný, že jeho výsledok, vždy dobovo a miestne podmienený, sa považuje za prirodzenost'." (s. 113) Napriek tejto kritike denaturácie človeka sa z neho nestáva utopista, nevolá po ideálnej spoločnosti, ani nehlása návrat do zlatého veku.

Vel'kým prínosom je Rousseauovo dielo v oblasti výchovy, predovšetkým výchovy k občianstvu, čo pre neho znamená predovšetkým výchovu k nesebeckému konaniu. Aj tu zostáva realistom, ked' poznamenáva, že vytvorit' z človeka občana nemožno za jeden deň. Richard St'ahel demaskuje a berie vietor z plachiet častej kritike osoby Jeana-Jacquesa Rousseaua, ktorá z neho robí otca moderných totalitarizmov a odporcu l'udských práv, ked' poskytuje svoju interpretáciu toho, ako to myslel Rousseau so svojím konceptom všeobecnej vôle, „donútením“ l'udí stat' sa slobodnými, „odovzdaním“ sa spoločenstvu, či ked' poukazuje na pasáže, kde Rousseau jasne odmieta dominanciu, právo silnejšieho i otroctvo a koncipuje základy l'udskoprávneho konceptu.

Richard St'ahel tiež podotýka, že francúzskeho myslitel'a možno pokladat' za jedného z prvých kritikov nadmernej produkcie a spotreby, ked' odhal'uje problém rastu (umelých) potrieb, čo vedie k zadlžovaniu a morálnemu úpadku spoločnosti. Pri jeho kritike redukovania hodnoty l'udskej bytosti na jeho čisto ekonomické aktivity ho vníma tiež aj ako oponenta ekonomizmu a „spoločnosti auditu“ (pojem prof. Michaela Powera).

Podl'a St'ahela Rousseau nie je zástanca egalitarizmu: rovnost' pre neho znamená iba rovnost' pred zákonom, nejde mu o rovnost' ako rovnakost', ale skôr rovnoprávnost'. Rousseau sa teda nestavia a priori proti súkromnému vlastníctvu, ale 
skôr volá po obmedzení extrémneho bohatstva a extrémnej chudoby. Preto vníma príjmovú polarizáciu ako jedno z vel'kých nebezpečenstiev, no nežiada revolučné vyvlastnenie v podobe násilného odnímania majetku bohatým, lež chce neúmernej akumulácii bohastva predchádzat', a to preventívne, odobraním prostriedkov na jeho hromadenie. Rousseau jednoznačne odmieta rovnú daň.

Podl'a Richarda St'ahela sú pre Rousseauove koncipovanie slobody určujúce dva javy: nerovnost' (predovšetkým v ekonomickej rovine) a závislost'. No nie je možné ich odstránit' úplne a ich následky možno iba tlmit'. Zaujímavá je aj úvaha o tom, ako zabezpečit' ochranu štátu a slobodu jeho občanov pred imperializmom, vel'mocenskou kolonizáciou alebo korporáciami. Tu autor podotýka, že Rousseauove riešenie $\mathrm{v}$ podobe konfederácie silných aktérov, sa $\mathrm{v}$ histórii neosvedčilo. Jeho teória spoločenskej zmluvy však ide d'alej než Hobbesova alebo Lockova, pretože v nej nenachádza iba ciel' zabezpečenia fyzickej existencie alebo ochrany majetku jednotlivca, ale využíva ju ako „nástroj normatívneho koncipovania spoločnosti aká by mohla a mala byt', a to vrátane inštitútov slobody a vlastníctva" (s. 159).

Úsilie autorov treba ocenit’ po viacerých stránkach. Publikácia má vd'aka prístupnému jazyku a jasnému štruktúrovaniu priam učebnicový charakter, no prináša prekvapenia v podobe nekonvenčných pohl'adov aj pre tých, ktorí sa považujú za znalcov súvislostí novovekej filozofie. Knižka je dôkazom, že zažité interpretácie, ktoré sú dnes „povinnou jazdou“ štúdia spoločenských vied, nesedimentovali, a hoci sa môžu zdat' samozrejmými, stále sú otvorené spochybneniu. Hoci autori „odhal'ujú busty“ známych filozofov, „oprašujú“ ich myšlienky cestou ich adaptácie do reálií súčasnej spoločnosti. Uskutočňujú tak potrebnú aktualizáciu tém človeka, jeho slobody a vlastníctva, čím pomáhajú ul'ahčit' nazeranie na vel'ké otázky a výzvy doby, ktorej sme aktérmi.

Michael Augustín

\section{Mgr. Michael Augustín}

Ústav politických vied SAV - Katedra politológie a európskych štúdií FF UKF v Nitre Dúbravská cesta 9

84104 Bratislava

Slovenská republika

michael.augustin.ma@gmail.com 